TAO, Vol. 16, No. 4, 885-896, October 2005

\title{
Carbon Dioxide and Radon Geohazards Over a Gas-bearing Fault in the Siena Graben (Central Italy)
}

\author{
Giuseppe Etiope ${ }^{1, *}$, Maurizio Guerra ${ }^{2}$ and Antonio Raschi ${ }^{3}$
}

(Manuscript received 30 June 2004, in final form 18 July 2005)

\begin{abstract}
The eastern master fault of the Siena Graben (central Italy), known as Rapolano Fault, is a place of migration of a large amount of $\mathrm{CO}_{2}$-rich gas from deep geothermal reservoirs. Under particular topographical and meteo-climatic conditions, large emissions of carbon dioxide can represent serious hazards to human and animal life. Carbon dioxide is a carrier gas for radon ( $R n)$, the concentrations of which are high in the soil despite the low $\mathrm{U}$ content of the overburden. $\mathrm{CO}_{2}$ pressure also drives the upwelling of thermal waters producing at the surface, in some places, radioactive $\left({ }^{226} \mathrm{Ra}\right.$ rich) travertine formations, inducing higher soil-gas Rn levels. Three main types of hazards, mechanical, toxicological and radio-ecological, may occur depending on the upwelling fluid phases (gas alone or gas plus water). Gas distribution and partitioning in different micro-environments (e.g., soil pores, groundwater, ground-atmosphere interface) should be taken into account when planning hazard-assessment surveys.
\end{abstract}

(Key words: Carbon dioxide, Radon, Gas-hazards, Faults)

\section{INTRODUCTION}

The Tyrrhenian-Apennine region of Central Italy is characterised by enhanced $\mathrm{CO}_{2}$ degassing from focused emissions (vents), diffuse soil exhalation and $\mathrm{CO}_{2}$-enriched groundwaters connected to geothermal fluids (Rogie et al. 2000; Morner and Etiope 2002). A large number of hazardous sites result from high concentrations of $\mathrm{CO}_{2}$ in topographic lows, representing lethal traps for humans and animals.

\footnotetext{
${ }^{1}$ Istituto Nazionale di Geofisica e Vulcanologia, Sezione Roma 2, Roma, ITALY

2 APAT, Agenzia per la Protezione dell'Ambiente e per i Servizi Tecnici, Roma, ITALY

${ }^{3}$ CNR - IBIMET, Istituto di Biometeorologia, Firenze, ITALY

* Corresponding author address: Dr. Giuseppe Etiope, Istituto Nazionale di Geofisica e Vulcanologia, Sezione Roma 2, Roma, ITALY; E-mail: Etiope@ingv.it
} 
The Rapolano Fault (Tuscany) is one of the most degassing sites in Italy as a result of increased permeability of rocks and high $\mathrm{CO}_{2}$ pressure gradients due to a deep geothermal reservoir (AA.VV. 1982; Barazzuoli et al. 1987; Duchi et al. 1992; Guerra and Etiope 1999). The $\mathrm{CO}_{2}$ concentrations in soil and atmospheric air close to the ground is so high that the area was chosen as a natural laboratory for experiments on plant physiology (Raschi et al. 1997).

Underground fluids (water and gas) circulation plays a major role in the local social economy: Thermal springs are resources for touristic and recreative activities; quarries of travertine, produced by the degassing and cooling of the thermal waters, and $\mathrm{CO}_{2}$ exploitation, for food and beverage industry, are viable economic sources. On the other hand, the huge and ready migration of deep-seated fluids to the atmosphere exposes the population to short- and long-term risks.

In this paper we examine available data from the Rapolano Fault (Tuscany) and show the occurrence of different hazards related to the migration of one-component (gas) and twocomponent (water and gas) systems. Data refer to gas concentration in the atmosphere just above the soil, in soil-pore air, in groundwater, and fluxes to the atmosphere.

\section{GEOLOGICAL SETTING}

The investigated area corresponds to the Neogene Siena-Radicofani basin, in central Italy, a graben formed during the post-Tortonian extensional phase of the Apennine orogenesis. The eastern edge of the basin is bordered by the Rapolano Fault (Fig. 1). The throw reaches $2000 \mathrm{~m}$ near Rapolano Terme village and decreases southward. The Mesozoic carbonate formations of the Tuscan nappe dip to the SW below the Pliocene marine clays and sands that fill the basin. The Rapolano Fault exercises dominant control over the local hydrothermal circulation (Barazzuoli et al. 1987; Liotta 1991), with a series of surface manifestations mainly characterised by gas-rich $\left(\mathrm{CO}_{2}\right)$ waters and gas vents. The hydrological and hydrochemical features of these manifestations were previously reported (e.g., Fancelli and Nuti 1975; Barazzuoli and Micheluccini 1982; Barazzuoli et al. 1986). Duchi et al. (1992) have interpreted the composition of gases discharged with waters as typical of low enthalpy geothermal systems; $\mathrm{CO}_{2}$ represents the most abundant gas (up to $99 \%$ ) and the $\mathrm{N}_{2}$ and $\mathrm{O}_{2}$ contents vary depending on the mixing with recharge waters. Water chemistry of Rapolano Fault springs $\left(\mathrm{Ca}-\mathrm{HCO}_{3}\right.$ type $)$ is different from that of springs occurring in the middle of the graben, such as along the transversal Arbia Fault or Arbia Line (Na-Cl type), and is affected by mixing with shallow aquifers (lower TDS and gas content). The type of manifestation (perennial, intermittent or geyser-like springs, dry gas vent) depends upon the relationship between depth of groundwater table and $\mathrm{CO}_{2}$ pressure.

The gas survey was performed in three key sites with major gas-hazard potential along the Rapolano Fault: Terme S. Giovanni, Bossoleto and Armaiolo.

Terme S. Giovanni hosts one of the main thermal springs of the region. In the site surveyed the Rapolano Fault is identified by a 150 -m long travertine ridge, formed by oversaturated $\mathrm{CO}_{2}$ waters. Here the geohazard is not related directly to $\mathrm{CO}_{2}$, but to the high levels of $\mathrm{Rn}$ and parent radionuclides. 


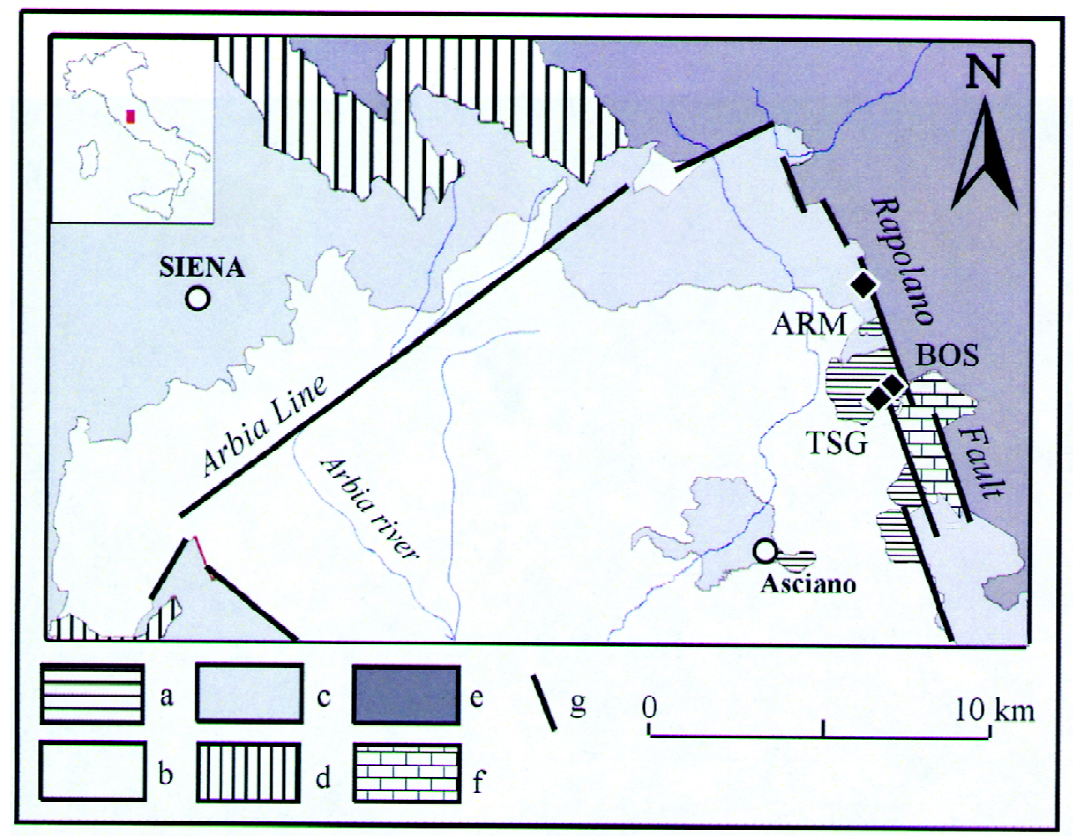

Fig. 1. Geological sketch map of the northernmost area of the Siena Basin and location of the gas-hazard sites examined; TSG: Terme S. Giovanni; BOS: Bossoleto; ARM: Armaiolo. Legend: (a) travertine (Holocene); (b) clay (Pliocene); (c) sand, clay, conglomerate and lacustrine deposits (Pliocene); (d) allochtonous flysch sequences (Cretaceous-Eocene); (e) sandstone and clay (Cretaceous-Paleogene); (f) carbonates (Mesozoic); (g) faults.

Bossoleto, about $100 \mathrm{~m}$ east of the S. Giovanni spring, is a tree-fringed bowl-like 6-m deep depression, with a diameter of about $80 \mathrm{~m}$. Gas emission points are located both at the bottom and on the flanks. This site, described for the first time about five centuries ago (Bacci 1571), presents evident dangers for the survival of animals and humans; in fact, several casualties have been recorded in the XIX century (Targioni Tozzetti 1840), and the site has been know as a suicide place. For this reason a wall was built around it (Rovini 1882); since then, it has been visited from time to time for harvesting firewood and for academic surveys. For some years, a small part of the area was used as a garden for vegetable production, but, in general, the wall prevented the grazing by domesticated animals, and other human utilization of the natural grassland.

Armaiolo site refers to a smaller depression (3 $\mathrm{m}$ deep) located in the northern sector of the Rapolano Fault. During our surveys it was not possible to stay and work in the site for more than 15 minutes, as the air was depleted of oxygen and rich in $\mathrm{CO}_{2}$. The depression is not enclosed and it actually represents a hazard for people and animals. 


\section{METHODOLOGY}

Gas-hazard evaluation was based on a series of field gas surveys performed since 1993 throughout the Rapolano Fault area (Miglietta et al. 1993; Etiope 1995; Guerra 1996; Lombardi et al. 1996; Guerra and Etiope 1999). For comparison, the gas survey was partially extended to the inner part of the graben, both on the Arbia Fault (see Fig. 1) and far from any local fault (Etiope 1995; Etiope and Lombardi 1997). The surveys included: measurements of $\mathrm{CO}_{2}$ concentration in the atmosphere within $1 \mathrm{~m}$ above the soil, soil-gas analysis (at $0.7 \mathrm{~m}$ below the ground), gas dissolved in groundwater, exhalation flux measurements by closed-chamber method (Etiope and Lombardi 1997), sampling of free gases from vents and bubbling pools by inverted funnels (see Guerra and Etiope 1999).

$\mathrm{CO}_{2}$ from soil-gas and groundwater was analysed in the laboratory within 10 days after sampling by quadrupole mass spectrometry. Dissolved gas was previously separated from the water phase in a vacuum line (Guerra 1996). Analyses of standards indicate that the analytical uncertainty is within $10 \%$ for samples collected in the gaseous phase whereas it reaches $15 \%$ for dissolved gas analyses, including also the extraction procedure. $\mathrm{CO}_{2}$ in atmospheric air was analysed by infrared gas-analyser (PP Systems, Hitchin, Herts. UK, Mod. EGM-1; span 0 - 2000 ppmv and $0-50000$ ppmv, accuracy \pm 1 ppmv; for higher concentrations, the gas was diluted in a closed loop connected to the gas analyser, as suggested by Sestak et al. 1971). Radon $\left({ }^{222} \mathrm{Rn}\right.$ ) was determined in the field using an $\alpha$ scintillation counter (EDA RDA 200). Dissolved ${ }^{222} \mathrm{Rn}$ was previously extracted by air stripping.

\section{RESULTS}

Table 1 summarises the values of $\mathrm{CO}_{2}$ and Rn occurring in the sub-systems investigated, i.e., soil-gas, groundwater, diffuse soil-atmosphere flux, vent, both in the fault zones (Rapolano Fault and Arbia Fault) and far from faults (Inner Basin) in the Siena Graben. At basin scale there is a wide range of values (e.g., 3 orders of magnitude for dissolved $\mathrm{CO}_{2}$ ) between samples collected along the faults and those collected in the inner basin.

The Rapolano Fault zone has the highest values of gas exhalation, coherently with the higher permeability of the rocks, gas pressure and absence of the Pliocene clay cover. In the Inner Basin the gas flux is systematically low, reflecting the normal soil respiration by biological activity and ${ }^{222} \mathrm{Rn}$ production in the soil (related to about $17 \mathrm{~Bq} \mathrm{~kg}^{-1}$ of ${ }^{226} \mathrm{Ra}$; Guerra and Etiope 1999). The gas flux along the Arbia Fault is intermediate between Rapolano Fault and Inner Basin: this is justified by the thick clay cover (about $400-600 \mathrm{~m}$ ) which partially and locally limits the gas migration along the tectonic discontinuity. The values of soil-gas and groundwater collected in the inner basin, taken as reference, are consistent with those from other non-fractured Italian sedimentary basins (Etiope and Lombardi 1995; Guerra 1996).

Table 2 summarises the $\mathrm{CO}_{2}$ and ${ }^{222} \mathrm{Rn}$ occurrence in the atmosphere, soil-gas, diffuse soil-atmosphere flux, and vent and groundwater in the three hazardous zones along the Rapolano Fault. 
Table 1. Mean values (minimum and maximum in brackets) of $\mathrm{CO}_{2}$ and ${ }^{222} \mathrm{Rn}$ in soil-gas, soil-atmosphere flux, gas vent and groundwater in the fault and unfaulted zones of the Siena Graben.

\begin{tabular}{|c|c|c|c|c|c|c|c|c|}
\hline \multirow[t]{2}{*}{ Zone } & \multicolumn{2}{|c|}{$\begin{array}{c}\text { Soil-gas } \\
\text { concentration }\end{array}$} & \multicolumn{2}{|c|}{$\begin{array}{c}\text { Soil-atmosphere } \\
\text { flux }\end{array}$} & \multicolumn{2}{|c|}{$\begin{array}{c}\text { Gas vent } \\
\text { composition }\end{array}$} & \multicolumn{2}{|c|}{$\begin{array}{l}\text { Groundwater } \\
\text { concentration }\end{array}$} \\
\hline & $\begin{array}{l}\mathrm{CO}_{2} \\
(\% \mathrm{v}) \\
\end{array}$ & $\begin{array}{c}{ }^{222} \mathrm{Rn} \\
\left(\mathrm{kBq} / \mathrm{m}^{3}\right) \\
\end{array}$ & $\begin{array}{c}\mathrm{CO}_{2} \\
\left(10^{-8} \mathrm{~m}^{3} \mathrm{~m}^{-2} \mathrm{~s}^{-1}\right) \\
\end{array}$ & $\begin{array}{c}{ }^{222} \mathrm{Rn} \\
\left(\mathrm{mBq} \mathrm{m}^{-2} \mathrm{~s}^{-1}\right)\end{array}$ & $\begin{array}{l}\mathrm{CO}_{2} \\
(\% \mathrm{~V}) \\
\end{array}$ & $\begin{array}{c}{ }^{222} \mathrm{Rn} \\
\left(\mathrm{kBq} / \mathrm{m}^{3}\right)\end{array}$ & $\begin{array}{c}\mathrm{CO}_{2} \\
(\mathrm{mmol} / \mathrm{L}) \\
\end{array}$ & $\begin{array}{c}{ }^{272} \mathrm{Rn} \\
\left(\mathrm{kBq} / \mathrm{m}^{3}\right)\end{array}$ \\
\hline $\begin{array}{l}\text { Rapolano } \\
\text { Fault }\end{array}$ & $\begin{array}{r}23.4 \\
(1.4-67.5) \\
11\end{array}$ & $\begin{array}{l}31.5 \\
(3.3-122) \\
\text { sites }\end{array}$ & $\begin{array}{r}263 \\
(0.8-1812) \\
I / s\end{array}$ & $\begin{array}{l}325.8 \\
(36.4-2180) \\
\text { sites }\end{array}$ & $\begin{array}{r}91.04 \\
(80.8-98.1) \\
6 \text { sit }\end{array}$ & $\begin{array}{l}19.5 \\
(10-33) \\
\text { ites })\end{array}$ & $\begin{array}{r}32.68 \\
(16.4-46.5) \\
6 \mathrm{si}\end{array}$ & $\begin{array}{c}0.65 \\
(0.3-1.9) \\
\text { ites }\end{array}$ \\
\hline $\begin{array}{l}\text { Arbia } \\
\text { Fault }\end{array}$ & $\begin{array}{c}8.2 \\
(0.9-64.3) \\
12\end{array}$ & $\begin{array}{l}22.2 \\
(6.8-40.3) \\
\text { sites }\end{array}$ & $\begin{array}{r}65 \\
(0.2-730) \\
12 \mathrm{~s}\end{array}$ & $\begin{array}{l}49.2 \\
(12.3-113) \\
\text { sites }\end{array}$ & $\begin{array}{r}86.15 \\
(78-94) \\
2 s i\end{array}$ & $\begin{array}{c}32 \\
(25-39) \\
\text { ites }\end{array}$ & $\begin{array}{r}24.43 \quad 3 \\
(0.1-52.2) \\
5 s i\end{array}$ & $\begin{array}{l}3.14 \text { (3sites) } \\
(0.2-8.8) \\
\text { ites }\end{array}$ \\
\hline $\begin{array}{l}\text { Inner } \\
\text { Basin }\end{array}$ & $\begin{array}{r}0.8 \\
(0.2-2.2) \\
12\end{array}$ & $\begin{array}{c}9 \\
(1.5-24.4) \\
\text { sites }\end{array}$ & $\begin{array}{r}1.1 \\
(0.1-5.4) \\
12 \mathrm{~s}\end{array}$ & $\begin{array}{l}28.5 \\
(3-70) \\
\text { ites }\end{array}$ & No ve & vents & $\begin{array}{r}0.067 \\
(0.05 \times 0.08) \\
2 s i\end{array}$ & $\begin{array}{l}3.19 \\
(0.8-5.6) \\
\text { ites }\end{array}$ \\
\hline
\end{tabular}

Table 2. Mean values (minimum and maximum in brackets) of $\mathrm{CO}_{2}$ and ${ }^{222} \mathrm{Rn}$ in the atmosphere, soil-gas, soil-atmosphere flux, gas vent and groundwater in the three hazardous sites along the Rapolano Fault.

\begin{tabular}{|c|c|c|c|c|c|c|c|}
\hline Site & Atmosphere & $\begin{array}{c}\text { Soil-gas } \\
\text { concentration }\end{array}$ & $\begin{array}{c}\text { Soil-atmosphere } \\
\text { flux }\end{array}$ & $\begin{array}{l}\text { Gas } \\
\text { compe }\end{array}$ & $\begin{array}{l}\text { vent } \\
\text { osition }\end{array}$ & $\begin{array}{l}\text { Grouno } \\
\text { concen }\end{array}$ & $\begin{array}{l}\text { Iwater } \\
\text { tration }\end{array}$ \\
\hline & $\begin{array}{l}\mathrm{CO}_{2} \\
(\% \mathrm{~V}) \\
\end{array}$ & $\begin{array}{lc}\mathrm{CO}_{2} & { }^{222} \mathrm{Rn} \\
(\% \mathrm{v}) & \left(\mathrm{kBq} / \mathrm{m}^{3}\right)\end{array}$ & $\begin{array}{cc}\mathrm{CO}_{2} & { }^{222} \mathrm{Rn} \\
\left(10^{-8} \mathrm{~m}^{3} \mathrm{~m}^{-2} \mathrm{~s}^{-1}\right)\left(\mathrm{mBq} \mathrm{m}^{-2} \mathrm{~s}^{-1}\right) \\
\end{array}$ & $\begin{array}{l}\mathrm{CO}_{2} \\
(\% \mathrm{~V})\end{array}$ & $\begin{array}{c}{ }^{222} \mathrm{Rn} \\
\left(\mathrm{kBg} / \mathrm{m}^{3}\right)\end{array}$ & $\begin{array}{c}\mathrm{CO}_{2} \\
(\mathrm{mmol} / \mathrm{L})\end{array}$ & $\begin{array}{l}{ }^{222} \mathrm{Rn} \\
\left.\mathrm{kBg} / \mathrm{m}^{3}\right)\end{array}$ \\
\hline TSG & $\begin{array}{c}<0.5 \\
(0.3 \mathrm{~m})\end{array}$ & $\begin{array}{cc}18.1 & 80 \\
(6.5-24.3) & (32.4-122) \\
9 \text { points }\end{array}$ & $\begin{array}{cc}14.5 & 84 \\
(3.2-23.3) & (55-103) \\
3 \text { points }\end{array}$ & 86.5 & 10 & 31.8 & 0.33 \\
\hline BOS & $\begin{array}{l}\text { up to } 80 \\
(1 \mathrm{~m})\end{array}$ & $>90$ & $\begin{array}{l}\text { total output } \\
3500 \mathrm{ty}^{-1}\end{array}$ & 96.1 & - & - & - \\
\hline ARM & $\begin{array}{c}1-10 \\
(0.3 \mathrm{~m})\end{array}$ & $\begin{array}{cc}66.6 & 3.4 \\
(65.8-67.5) & (3.3-3.5) \\
2 \text { points }\end{array}$ & $\begin{array}{cc}1318 & 1495 \\
(824-1812) & (810-2180) \\
2 \text { points }\end{array}$ & 98.1 & 33 & 46.5 & 0.3 \\
\hline
\end{tabular}




\subsection{Terme S. Giovanni}

The soil-air surrounding the travertine ridge is enriched in $\mathrm{CO}_{2}$ (up to $24 \%$ ) up to $20-30 \mathrm{~m}$ from the ridge axis. This site is particularly interesting for the high values of ${ }^{222} \mathrm{Rn}$ in the soilair (up to $120 \mathrm{kBq} \mathrm{m}^{-3}$; Fig 2). The analyses of radionuclides in the soil and travertine samples showed high concentration of ${ }^{226} \mathrm{Ra}$ (from 37 to $44 \mathrm{~Bq} \mathrm{~kg}^{-1}$ ). The theoretical maximum value of ${ }^{222} \mathrm{Rn}$ produced in the soil by its ${ }^{226} \mathrm{Ra}$ parent has been estimated to be within $64 \mathrm{kBq} \mathrm{m}^{-3}$, considering generous values of the soil emanation coefficient (Guerra and Etiope 1999).
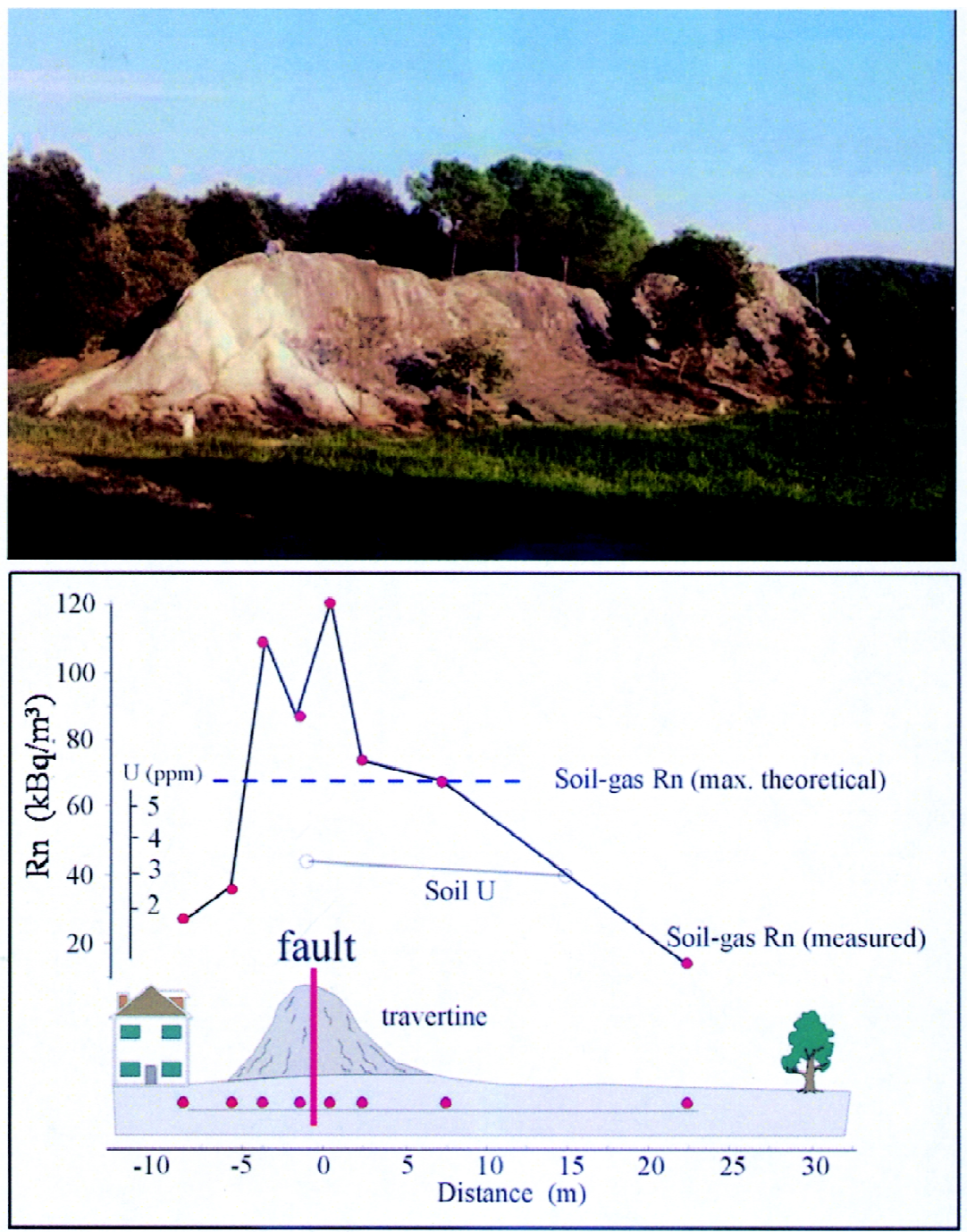

Fig. 2. Terme S. Giovanni travertine ridge and related radon profile (from Guerra and Etiope 1999). 
Accordingly, ${ }^{222} \mathrm{Rn}$ values above $70 \mathrm{kBq} \mathrm{m}^{-3}$ should be the result of gas migration from the subsoil. The data suggest that a significant amount of soil-gas ${ }^{222} \mathrm{Rn}$ migrated from subsoil; this process is quite normal in the presence of large emissions of $\mathrm{CO}_{2}$, acting as an effective carrier for trace gases (Etiope and Martinelli 2002; Yang et al. 2003). ${ }^{222}$ Rn dissolved in groundwater, instead, is quite low $\left(0.3 \mathrm{kBq} \mathrm{m}^{-3}\right)$. This can be explained by an inverse correlation between $\mathrm{CO}_{2}$ flux and trace gases dissolved in groundwater due to bubble "stripping" phenomena, evidenced in detail in the main gas vents of the Siena Graben (Guerra and Etiope 1999).

\subsection{Bossoleto}

About 3500 tons of gas are released annually (Morner and Etiope 2002). Gas emissions are mainly composed by $\mathrm{CO}_{2}$ (96\%); minor gases include nitrogen (3.4\%), methane $(0.5 \%)$, hydrogen sulphide $(0.02 \%) . \mathrm{H}_{2} \mathrm{~S}$ rapidly oxidises in contact with the air and is greatly diluted in the atmosphere. Atmospheric $\mathrm{H}_{2} \mathrm{~S}$ levels are below $0.0001 \mu \mathrm{mol} \mathrm{mol}{ }^{-1}$ when $\mathrm{CO}_{2}$ is about $5000 \mu \mathrm{mol} \mathrm{mol}^{-1}$. Atmospheric $\mathrm{CO}_{2}$ concentrations vary during the day, and partly depend on atmospheric conditions. The maximum concentration recorded was $80 \%$ one meter above the ground. Concentrations as high as $75 \%$ have been frequently measured between 7 and $8 \mathrm{am}$. At this time of the day it is possible to see the refractive boundary between the region with very high $\mathrm{CO}_{2}$ and the more normal, less dense air above it. The boundary tends to become unstable as soon as direct solar radiation is incident on the zone at the bottom of the doline. Then the high concentration is rapidly dispersed dropping to levels of $2000 \mu \mathrm{mol} \mathrm{mol}^{-1}$.

Other environmental factors are influenced by the combination of topography and carbon dioxide emissions; the most marked example is observed for air temperature which shows a rapid increase in the early morning, associated with the presence of the stable atmospheric conditions at the bottom of the doline. This heating is associated with an enhanced greenhouse effect resulting from the high $\mathrm{CO}_{2}$ concentration at the bottom. When direct solar radiation is incident on the high $\mathrm{CO}_{2}$ atmosphere, a sudden temperature increase takes place; temperature decreases to more "normal" values when buoyancy promotes air mixing.

Other analyses (Schulte et al. 1999) showed that the atmospheric sulphur compounds fluctuate strongly in the morning until 9 am with a mean concentration of $22 \mathrm{ppbv}$ (max 83 ppbv; min 2 ppbv) for $\mathrm{H}_{2} \mathrm{~S}$ and $12 \mathrm{ppbv}$ ( $\max 23 \mathrm{ppbv}$; min $5 \mathrm{ppbv}$ ) for $\mathrm{SO}_{2}$. Thereafter, the gas mixing ratio of both gases declines rapidly to almost constant values of $5 \pm 1 \mathrm{ppbv}\left(\mathrm{H}_{2} \mathrm{~S}\right)$ and $6 \pm 1 \mathrm{ppbv}\left(\mathrm{SO}_{2}\right)$ from 9 am to $6 \mathrm{pm}$. Subsequently, atmospheric mixing ratios of $\mathrm{H}_{2} \mathrm{~S}$ and $\mathrm{SO}_{2}$ increase again to higher strongly fluctuating values.

\subsection{Armaiolo}

Three main vents annually emit in total around 4400 tons of gas (Morner and Etiope 2002). $\mathrm{CO}_{2}$ concentrations $>10000 \mu \mathrm{mol} \mathrm{mol}^{-1}$ were measured at a height of $0.3 \mathrm{~m}$ above soil, around the largest vent, located in a narrow ditch; $\mathrm{H}_{2} \mathrm{~S}$, easily detectable from its smell, is present in the emitted gas, but its concentration has never been measured (Miglietta et al. 1993). Soil $\mathrm{CO}_{2}$ reaches $66 \%$. In correspondence with the gas vents ${ }^{222} \mathrm{Rn}$ concentration in 
soil is relatively low $\left(\sim 3 \mathrm{kBq} \mathrm{m}^{-3}\right)$ but its flux is quite high (order of $10^{3} \mathrm{mBq} \mathrm{m}^{-2} \mathrm{~s}^{-1}$ ); this can be explained by an effect of "suction" produced by the high $\mathrm{CO}_{2}$ flux; the rapid transport of ${ }^{222} \mathrm{Rn}$ into the channel (vent) prevents any accumulation in the soil pores. Groundwater

${ }^{222} \mathrm{Rn}$ concentration is low, similar to Terme S. Giovanni.

Carbon dioxide concentration in the atmosphere of the ditch is highly variable, in consequence of the slope and of the uneven terrain. With favourable wind conditions, the $\mathrm{CO}_{2}$ "cloud" reaches an olive orchard located $150 \mathrm{~m}$ west of the gas vents. Around the crowns of the trees growing on the raised edges of the ditch, a mean $\mathrm{CO}_{2}$ concentration of $2214 \pm 143 \mu \mathrm{mol} \mathrm{mol}^{-1}$ was measured; daily and seasonal variations were small (Jones et al. 1995).

\section{DISCUSSION AND CONCLUSION}

"Gas-hazard" is defined as any gas-related process inducing direct or indirect risks for humans and their economical and social activity. In the Rapolano Area the enhanced fluid circulation related to faulting may have positive economical and social implications, but also exposes the population to gas-hazards. The evaluation of these hazards constitutes a substantial element in the management of the thermal resource.

At Rapolano, two scenarios of occurrence of geo-fluids on the ground can be recognised (Fig. 3):

- migration of a two-component (water and gas) system (e.g., Terme S. Giovanni);

- migration of a one-component (gas) system (e.g., Bossoleto and Armaiolo).

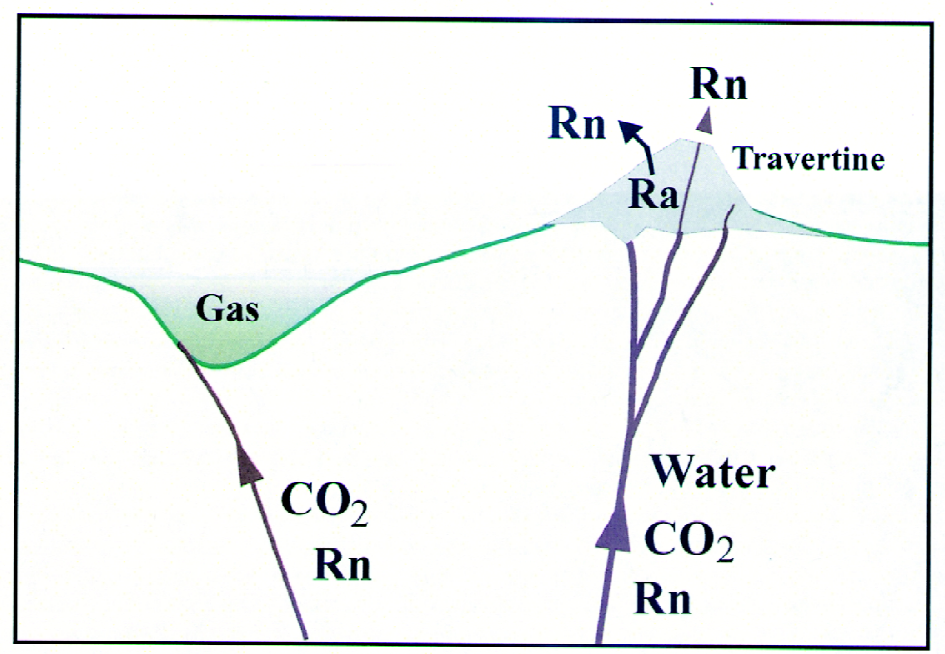

Fig. 3. Examples of toxicological and radioactive gas-hazards produced by faultlinked gas channelling: morphology-linked gas accumulation, such as at Bossoleto and Armaiolo (left), solid-phase precipitation, such as at Terme S. Giovanni (right). 
The first case includes springs generally controlled by gas pressure, sometimes with gas uplift mechanism (Terme S. Giovanni and other springs in the Rapolano village). The second case includes dry gas vents as well as "invisible" $\mathrm{CO}_{2}$ exhalation from soil.

In both circumstances the gas escape (mainly $\mathrm{CO}_{2}, \mathrm{Rn}$ and volatile sulphur compounds) can induce radio-ecological and toxicological hazards (Fig. 4). Radio-ecological hazard is however higher in the first case due to higher radon levels induced by ${ }^{226} \mathrm{Ra}$-rich carbonate precipitates formed at the thermal water's discharge (e.g., travertines of Terme S. Giovanni). Such deposits can also obstruct natural and artificial (i.e., filter columns) hydraulic pathways affecting wells/springs efficiency (mechanical gas-hazard). Decreasing flow rate, frequently observed in the area, could be related to this phenomenon. This occurs mainly where $\mathrm{H}_{2} \mathrm{~S}$ is lower; the presence of $\mathrm{H}_{2} \mathrm{~S}$, keeping $\mathrm{pH}$ low, limits the carbonate deposition. The solubility of most radionuclide compounds in groundwater depends on physico-chemical parameters $(\mathrm{pH}$, Eh, temperature) that in turn may change in response of hydrogeological processes such as $\mathrm{CO}_{2}$ degassing, groundwater cooling, mixing of aquifers etc.

Data show that at Terme S. Giovanni the high exhalation of radon originate both from this surplus of parent radionuclides and to the stripping of $\mathrm{Rn}$ by $\mathrm{CO}_{2}$ bubbles from water. In urbanised areas the high radioactivity of precipitates can demand remediation and radioprotection actions. An indoor radon survey in dwellings is recommended to assess the actual radio-ecological hazard.

High and well-localised $\mathrm{CO}_{2}$ exhalation occurring in morphological depressions (Bossoleto and Armaiolo) in particular meteo-climatic conditions (e.g., early hours in the morning) allows the stratification of "heavy" carbon dioxide. Measurements at Bossoleto clearly indicate that carbon dioxide concentration in the first $100 \mathrm{~cm}$ above the soil surface can reach $80 \%$ thus depleting oxygen and resulting in the symptoms of asphyxia for humans (toxicological hazard). $\mathrm{H}_{2} \mathrm{~S}$ concentrations at Bossoleto seem not to reach hazardous levels (a few ppb versus hundreds of ppm). Heavy gas can also penetrate and accumulate in the underground, closed, natu-

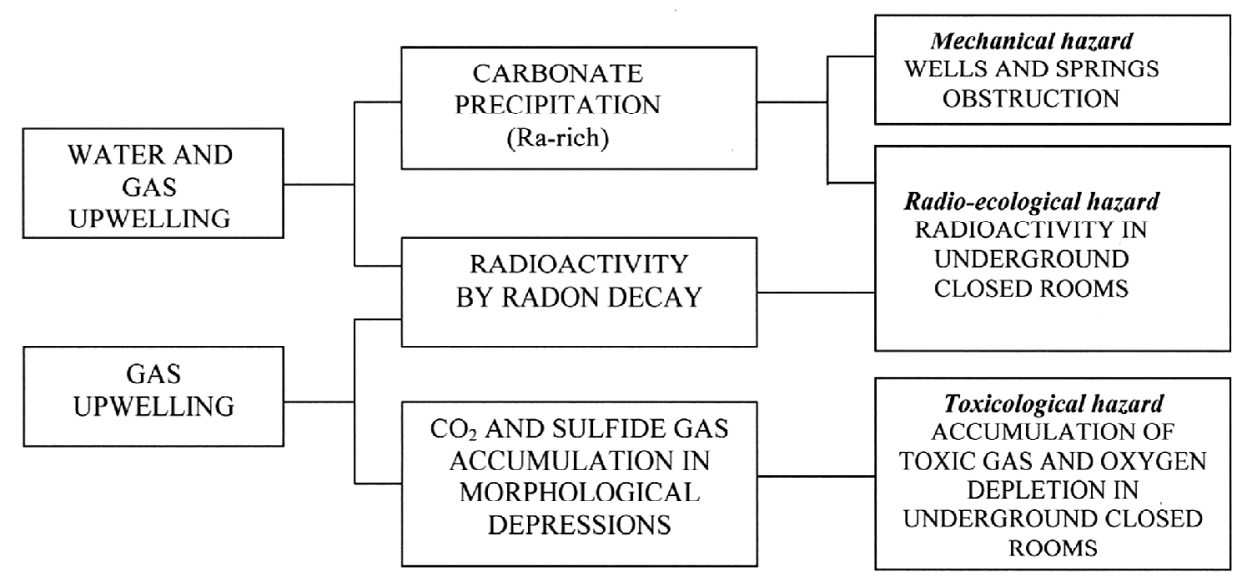

Fig. 4. Possible geo-hazards, related to fluids circulation in the Rapolano Fault geothermal area. 
ral or artificial rooms (caves, cellars) creating short- and long-term risk sources.

Gas behaviour at Armaiolo highlights the role of the carrier gas for the migration and accumulation in vents of trace gases, including Rn. Data suggest that along the main pathways the ascending gas column can "suck" trace gases from the neighbouring volume of rock. This process seems to occur both above (Bernoulli effect, as seen at Armaiolo) and below (stripping, as seen at Terme S. Giovanni) the groundwater table (Guerra and Etiope 1999). This observation is fundamental when planning surveys for the determination of Rn-prone risk areas. It indicates that the assessment of effective radon potential requires the analysis of the whole geological environment. This means that groundwater, or soil pore atmosphere or Ra determination in soil, alone may not provide data representative of Rn occurrence and abundance at the investigated site. The radiation protection zoning programme should possibly prefer, for the spatial support of surveys, a "Bayesian" approach that considers geological features significant for radon distribution (e.g., faulting, $\mathrm{CO}_{2}$ emanation, travertine outcropping, thermal springs), instead of a totally random sampling or sampling based on classical parameters ( $\mathrm{Ra}$ content in soil/rock, porosity, density).

The interaction of deep-seated fluids (water and gas) with surface aquifers produces oxidation/reduction, dilution/concentration reactions, changes of $\mathrm{pH}$ that in turn cause precipitation and dissolution of mineral (generally carbonate) phases. Changes during time of deep and shallow hydraulic contributions can increase and decrease the permeability of hydraulic pathways, i.e., modify the local pattern of the fluid migration and discharge, as recognised at the Terme S. Giovanni "ridge".

Rapolano Terme Fault can therefore be considered a reference site for gas-hazard studies. A series of gas emission processes, and the origin and evolution of the main factors leading to gas-hazards, such as gas-water interaction, solid-phase precipitation, fault-linked gas channelling and morphology-linked gas accumulation, can be examined with great detail. It is evident that for a correct gas-hazard evaluation, all the different microenvironments hosting the fluid phases (groundwater, soil, vents, soil-atmosphere interface) must be analysed simultaneously and compared.

Acknowledgements Thanks are due to the Rapolano Terme municipality for support and cooperation, and to Jens Heinicke and an anonymous reviewer for helpful comments.

\section{REFERENCES}

AA. VV., 1982: Il graben di Siena. CNR, PFE, SPEG, R.F. 9, PEG ed. Milano.

Bacci, A., 1571: De Thermis. Valgrisium, Venezia.

Barazzuoli, P., and M. Micheluccini, 1982: Il graben di Siena: Idrologia ed aspetti idrogeologici. In: Il graben di Siena. CNR, PFE, SPEG, R.F. 9, PEG ed. Milano.

Barazzuoli, P., A. Costantini, A. Lazzarotto, M. Micheluccini, M. Salleolini, L. Salvadori, and F. Sandrelli, 1986: Ricerche strutturali ed idrogeologiche sulle aree alimentatrici del serbatoio geotermico. In: Atti del seminario informativo sulle attività di ricerca del Sottoprogetto Energia Geotermica. CNR, PFE, SPEG, SI 4, 175-189. 
Barazzuoli, P., A. Costantini, S. Grassi, A. Lazzarotto, M. Micheluccini, F. Piantelli, M. Salleolini, F. Sandrelli, P. Squarci, L. Taffi, and G. Veronesi, 1987: L'energia geotermica in provincia di Siena. Internal Report. Amministrazione provinciale di Siena.

Duchi, V., A. Minissale, M. Paolieri, F. Prati, and A. Valori, 1992: Chemical relationship between discharging fluids in the Siena-Radicofani graben and the deep fluids produced by the geothermal fields of Mt. Amiata, Torre Alfina and Latera (Central Italy). Geothermics, 21, 401-413.

Etiope, G., 1995: Migrazione e comportamento del "Geogas" in bacini argillosi. Ph.D. Thesis. Dept. of Earth Sci., Univ.. "La Sapienza" Rome, 210 pp.

Etiope, G., and S. Lombardi, 1995: Evidence for radon transport by carrier gas through faulted clays in Italy. J. Radioanal. Nucl. Chem., 193, 291-300.

Etiope, G., and S. Lombardi, 1997: Levels of $\mathrm{CO}_{2}$ leakage in relation to geology. In: Raschi, Miglietta, Tognetti, and van Gardigen (Eds.), Plant Responses to Elevated $\mathrm{CO}_{2}$, Evidence from natural springs. Cambridge Univ. Press, 21-33.

Etiope, G., and G. Martinelli, 2002: Migration of carrier and trace gases in the geosphere: an overview. Phys. Earth Planet. Inter., 129, 185-204.

Fancelli, R., and S. Nuti, 1975: Studio sulle acque termali e minerali della parte orientale della provincia di Siena. Boll. Soc. Geol. It., 94, 135-155.

Guerra, M., 1996: I gas disciolti nelle acque e loro significato nelle indagini strutturali ed idrogeologiche. Ph.D. Thesis. Dept. of Earth Sci., Univ.. "La Sapienza" Rome.

Guerra, M., and G. Etiope, 1999: Effects of gas-water partitioning, channelling and stripping processes upon radon and helium gas distribution in fault areas. Geochem. J., 33, 141151.

Jones, M. B., J. Clifton-Brown, A. Raschi, and F. Miglietta, 1995: The effects on Arbutus unedo L. of long-term exposure to elevated $\mathrm{CO}_{2}$. Global Change Biol., 1, 295-302.

Liotta, D., 1991: The Arbia-Val Marecchia Line, Northern Apennines. Eclogae Geol. Helv., 84, 413-430.

Lombardi, S., G. Etiope, M. Guerra, G. Ciotoli, P. Grainger, G. A. Duddridge, F. Gera, V. Chiantore, R. Pensieri, P. Grindrod, and M. Impey, 1996: The refinement of soil gas analysis as a geological investigative technique. Final Report EC contract $\mathrm{n}^{\circ}$ FI2WCT91-0064. $4^{\text {th }} \mathrm{R} \& \mathrm{D}$ programme on "Management and Storage of Radioactive Waste" (1990-1994) Part A, Task 4: "Disposal of Radioactive Waste". Official publication of the European Communities n ${ }^{\circ}$ EUR 16929 EN, 192 pp.

Miglietta, F., A. Raschi, I. Bettarini, R. Resti, and F. Selvi, 1993: Natural $\mathrm{CO}_{2}$ springs in Italy: a resource for examining long-term response of vegetation to rising atmospheric $\mathrm{CO}_{2}$ concentrations. Plant, Cell Environ., 16, 873-878.

Morner, N. A., and G. Etiope, 2002: Carbon degassing from the lithosphere. Global Planet. Change, 33, 185-203.

Raschi, A., F. Miglietta, R. Tognetti, and P. R. van Gardingen, 1997: Plant responses to elevated $\mathrm{CO}_{2}$. Evidence from natural springs. Campbridge Univ. Press., $272 \mathrm{pp}$.

Rogie, J. D., D. M. Kerrick, G. Chiodini, and F. Frondini, 2000: Flux measurements of non volcanic $\mathrm{CO}_{2}$ emission from some vents in central Italy. J. Geophys., Res., 105, 84358445. 
Rovini, V., 1882: Topografia e statistica medica del Comune di Rapolano. G. Civelli (Ed.), Milano, $111 \mathrm{pp}$.

Schulte, M., F. G. Raiesi, H. Papke, K. Butterbach-Bahl, N. van Breemen, and H. Rennenberg, 1999: $\mathrm{CO}_{2}$ concentration and atmospheric trace gas mixing ratio around natural $\mathrm{CO}_{2}$ vents in different Mediterranean forests in Central Italy. In: Raschi, A., F. P. Vaccari, and F. Miglietta (Eds.), Ecosystem response to $\mathrm{CO}_{2}$ The MAPLE project results. 168188, European Commission, Office for Official Publ. of the European Communities.

Sestak, Z., J. Catsky, and P. G. Jarvis, 1971: Plant Photosynthetic Production - Manual of Methods. Dr. W. Junk Pub., The Hague, 818 pp.

Targioni Tozzetti, A., 1840: Dei nuovi bagni minerali di S. Maria delle Nevi a Rapolano. Galletti, Firenze.

Yang, T. F., C. Y. Chou, C. H. Chen, L. L. Chyi, and J. H. Jiang, 2003: Exhalation of radon and its carrier gases in SW Taiwan. Radiat. Meas., 36, 425-429. 